\title{
Pendekatan Eksplorasi Berbasis Intuisi Pada Kemampuan Pemecahan Masalah Matematis
}

\author{
E Susilawati $^{1, *}$, A. H. Syaf ${ }^{1}$, dan W. Susilawati ${ }^{1}$, \\ ${ }^{1}$ Prodi Pendidikan Matematika, UIN Sunan Gunung Djati Bandung, \\ Jl. A.H. Nasution No. 105, Bandung 40614, Indonesia \\ "E-mail:pmtk@uinsgd.ac.id
}

Dikirim: 03 Agustus 2017 ; Diterima: 24 November 2017; Dipublikasikan: 20 Desember 2017

\begin{abstract}
Abstrak. Penelitian ini merupakan penelitian eksperimen yang bertujuan untuk meningkatkan kemampuan pemecahan masalah matematis antara siswa yang memperoleh pembelajaran pendekatan eksplorasi berbasis intuisi dengan siswa yang memperoleh pembelajaran konvensional berdasarkan PAM. Data diperoleh melalui instrumen tes dan nontest yang diberikan kepada 74 siswa SMP kelas VIII yang terdiri dari 37 siswa pada kelas eksperimen, dan 37 siswa pada kelas kontrol. Berdasarkan hasil pengolahan data bahwa terdapat perbedaan peningkatan kemampuan pemecahan masalah matematis antara siswa yang memperoleh pembelajaran pendekatan eksplorasi berbasis intuisi dengan siswa yang memperoleh pembelajaran konvensional secara keseluruhan berdasarkan PAM (pandai, cukup, lemah). Aktivitas guru dan siswa pada saat pembelajaran dengan pendekatan eksplorasi berbasis intuisi telah terlaksana dengan baik. Pendekatan eksplorasi berbasis intuisi dapat memfasilitasi proses intuisi, penemuan konsep, dan aplikasi konsep sehingga kemampuan pemecahan masalah matematis siswa lebih baik dari pada pembelajaran konvensional.
\end{abstract}

Kata Kunci. Pemecahan Masalah Matematis, Eksplorasi Berbasis Intuisi.

\section{Pendahuluan}

Kemampuan pemecahan masalah matematika adalah kemampuan atau kecakapan seseorang dalam memecahkan suatu masalah matematika. Pemecahan masalah matematika merupakan proses yang digunakan seseorang untuk menyelesaikan suatu masalah matematika. Menurut Stemberg dan Ben-Zee (Kadir,
2010: 37) menyatakan pemecahan masalah adalah suatu proses kognitif yang membuka peluang pemecahan masalah untuk bergerak dari suatu keadaan yang tidak diketahui bagaimana pemecahannya ke suatu keadaan tetapi tidak mengetahui bagaimana memecahkannya. 
Pemecahan masalah bahkan sebagai jantung dari pembelajaran matematika. Hal ini sebagaimana (Sumarmo (1994) dalam Fauziah, 2010:1) menyatakan bahwa pemecahan masalah merupakan hal yang sangat penting sehingga menjadi tujuan umum pengajaran matematika bahkan sebagai jantungnya matematika. Sumarmo (2007) mengemukakan pemecahan masalah matematis mempunyai dua makna, yaitu: (a) Sebagai suatu pendekatan pembelajaran, yang digunakan untuk menemukan kembai (reinvention) dan memahami materi/konsep/prinsip matematika,

Sebagai tujuan atau kemampuan yang harus dicapai. Polya (Kusumawati, 2010: 35) menguraikan secara rinci empat langkah dalam menyelesaikan masalah yang disajikan secara terurut, yaitu: (a) Understanding the problem (memahami masalah), (b) Devising a plan (merencanakan penyelesaian), (c) Carriying out the plan (melaksanakan rencana), dan (d) Looking back (memeriksa kembali proses dan hasil). Salah satu tujuan dalam pembelajaran matematika adalah membantu siswa dalam menyelesaikan pemecahan masalah, baik itu masalah yang berhubungan dengan pemahaman konsep matematika itu sendiri maupun yang berhubungan dengan masalah dalam kehidupan sehari-hari.
Studi pendahuluan di SMP yang diteliti menunjukkan rendahnya kemampuan pemecahan masalah matematis siswa. Salah satu faktor rendahnya kemampuan pemecahan masalah matematis siswa adalah kurangnya keinginan siswa mempelajari mata pelajaran matematika karena dianggap sulit, menyeramkan dan lain sebagainya. Hal ini sebagaimana yang diungkapkan oleh Wahyudin (2008: 338) bahwa matematika merupakan mata pelajaran yang sulit untuk diajarkan maupun dipelajari. Salah satu alasan mengapa demikian adalah karena dalam mempelajari materi baru dalam matematika seringkali memerlukan pengetahuan dan pemahaman yang memadai tentang satu atau lebih materi yang telah dipelajari sebelumnya.

Menyadari pentingnya kemampuan pemecahan masalah matematis, maka diperlukan keterampilan guru dalam menerapkan pembelajaran yang mampu mengkonstruksi mengembangkan sifat kemandirian belajar siswa. Salah satu pembelajaran dalam matematika yang diharapkan dapat meningkatkan kemampuan pemecahan masalah matematis siswa adalah pendekatan eksplorasi. Pendekatan eksplorasi merupakan salah satu pendekatan yang berlandaskan pada teori kontruktivisme. Teori kontruktivisme 
merupakan teori yang mendukung pelaksanaan kegiatan pembelajaran yang berpusat pada siswa. (Novianti, Isrok'atun, \& Kurniadi, 2016). Pendekatan eksplorasi merupakan suatu pendekatan yang bertujuan untuk menggali ide-ide, argumenargumen dan cara-cara yang berbeda dari siswa melalui sejumlah pertanyaanpertanyaan terbuka dan perintah-perintah sehingga dapat mengantarkan siswa kepada pemahaman suatu konsep serta penyelesaian masalah-masalah.

Dalam pendekatan ini siswa menjadi penjelajah aktif (active eksplorer) dan guru hanya berperan sebagai pembimbing dan fasilitator eksplorasi tersebut. Tujuan dari kegiatan eksplorasi matematika adalah agar siswa terlibat secara luas dalam pemecahan masalah. Peran guru dalam kegiatan eksplorasi adalah sebagai fasilitator dan guide selama proses pembelajaran berlangsung.

Adapun Rohmat (2014: 18) mengungkapkan peran guru dalam pendekatan eksplorasi, diantaranya: 1) Melibatkan siswa mencari informasi yang luas dan dalam tentang topik/tema materi yang akan dipelajari serta belajar dari aneka sumber, 2) Guru harus menggunakan beragam pendekatan pembelajaran, media pembelajaran dan sumber belajar lain, 3) Memfasilitasi terjadinya interaksi antar siswa dengan siswa, siswa dengan guru, lingkungan, dan sumber belajar lainnya, 4) Melibatkan peserta didik secara aktif dalam setiap kegiatan pembelajaran, 5) Memfasilitasi peserta didik melakukan percobaan di laboratorium, studio, atau lapangan. Mengenai keterlibatan intuisi, Fischbein (2005) mendefinisikan intuisi adalah kognisi segera dalam memperoleh dan memahami sesuatu yang bergantung pada suatu proses penalaran dan tanpa pembenaran atau bukti-bukti serta mempunyai beberapa karakteristik. Intuisi merupakan proses mendapatkan sesuatu secara langsung/tiba-tiba, tidak memerlukan referensi atau pembuktian berdasarkan fakta-fakta (deduktif) terkadang memerlukan pertimbangan empiris (induktif) namun hasilnya dianggap sebagai suatu kebenaran. Pendekatan eksplorasi berbasis intuisi yang dimaksud adalah merujuk pada pendekatan eksplorasi secara umum, tetapi pada setiap awal pembelajaran setelah tahap persiapan, terlebih dahulu diberikan tahap intuitif sebelum tahap penemuan konsep, dan aplikasi konsep. Tahap intuitif merupakan tahap mengajukan pertanyaan/masalah yang mengutamakan jawaban intuitif. Jawaban intuitif adalah jawaban yang didapat secara langsung/tiba-tiba, tidak memerlukan pembuktian formal terkadang memerlukan pertimbangan induktif. Tahap 
intuitif digunakan untuk memancing jawaban formal sebelum berfikir matematika secara formal melalui tahap eksplorasi. Dengan demikian, rumusan masalah pada penelitian ini adalah apakah terdapat perbedaan peningkatan kemampuan pemecahan masalah matematis

\section{Metodologi Penelitian}

Metode yang digunakan adalah metode eksperimen dengan quasi experimental design dan bentuk desainnya adalah pretestposttest control group design. Sampel diambil dari populasi menggunakan teknik random sampling dengan jumlah sampel

\section{Hasil dan Pembahasan}

Berdasarkan hasil penelitian yang dilakukan maka diperoleh data mengenai aktivitas guru dan siswa terhadap pembelajaran matematika menggunakan antara siswa yang memperoleh pembelajaran pendekatan eksplorasi berbasis intuisi dengan siswa yang memperoleh pembelajaran konvensional ditinjau secara keseluruhan berdasarkan PAM (pandai, cukup, lemah)?

sebanyak 74 siswa SMP. Data diperoleh dari hasil instrumen penelitian yaitu, tes PAM, tes kemampuan pemecahan masalah matematis (pretest dan posttest), serta lembar observasi guru dan siswa.

pendekatan eksplorasi berbasis intuisi. Data yang diperoleh mengenai aktivitas guru disajikan pada tabel 3.1 .

Tabel 3.1 Persentase Aktivitas Guru Selama Proses Pembelajaran

\begin{tabular}{ccc}
\hline $\begin{array}{c}\text { Pertemuan } \\
\text { Pembelajaran }\end{array}$ & Persentase (\%) & Kategori \\
\hline Pertemuan Ke-1 & 86,67 & Sangat Baik \\
\hline Pertemuan Ke-2 & 100 & Sangat Baik \\
\hline Pertemuan Ke-3 & 100 & Sangat Baik \\
\hline
\end{tabular}

Berdasarkan tabel 3.1, kualitas aktivitas guru mengalami peningkatan pada setiap pertemuan dan juga pada setiap tahapan dalam pendekatan eksplorasi berbasis intuisi. Pada pertemuan pertama, pada aktivitas awal pembelajaran guru sudah baik dalam mengkondisikan siswa, memberikan motivasi dan menyampaikan tujuan pembelajaran, begitu juga pada saat memberikan apersepsi dengan pertanyaanpertanyaan terbuka dan menyampaikan alur pembelajaran sudah baik. Hal ini dikarenakan guru sudah mempersiapakan dengan cukup baik sebelum pembelajaran 
dimulai. Pada aktivitas saat pembelajaran menggunakan pendekatan eksplorasi, guru sudah baik dalam memberikan masalah intuitif, memberikan kesempatan kepada siswa untuk menyampaikan jawaban intuitif. Pada tahap melaksanakan langkahlangkah eksplorasi, guru juga sudah baik memberikan kesempatan kepada siswa untuk bertanya dan berinteraksi langsung dengan guru maupun teman. Namun dalam melaksanakan langkah-langkah eksplorasi tersebut siswa masih terlihat kebingungan, hal ini karena siswa belum terbiasa melakukan langkah-langkah eksplorasi untuk menemukan konsep dari materi yang sedang dipelajari. Pada pertemuan berikutnya aktivitas guru semakin baik atas saran dari observer. Selanjutnya persentase aktivitas siswa selama proses pembelajaran menggunakan pendekatan eksplorasi berbasis intuisi disajikan pada tabel 3.2.

Tabel 3.2 Persentase Aktivitas Siswa Selama Proses Pembelajaran

\begin{tabular}{ccc}
\hline Pertemuan pembelajaran & Persentase $(\%)$ & Kategori \\
\hline Pertemuan Ke-1 & 70,45 & Cukup \\
\hline Pertemuan Ke-2 & 81,71 & Baik \\
\hline Pertemuan Ke-3 & 85,40 & Baik
\end{tabular}

Beradasarkan tabel 3.2, aktivitas siswa terlihat bahwa mengalami peningkatan pada setiap pertemuan dan juga pada setiap aspek yang diamati dalam pembelajaran matematika menggunakan pendekatan eksplorasi berbasis intuisi. Pada pertemuan pertama siswa belum melakukan langkahlangkah eksplorasi dengan aktif, mereka jarang bertanya atau mengeluarkan pendapat. Pada saat guru menunjuk beberapa siswa untuk menyampaikan hasil jawaban, mereka masih malu-malu. Hal ini disebabkan siswa belum terbiasa dengan pembelajaran matematika menggunakan pendekatan eksplorasi berbasis intuisi. Pada pertemuan berikutnya siswa sudah mulai aktif dalam mengikuti langkah-langkah eksplorasi dengan masksimal dan mengajukan pertanyaan-pertanyan apabila ada yang belum dipahami.

Siswa mulai terbiasa dalam menyampaikan jawaban intuitif maupun jawaban hasil yang diperoleh setelah langkah-langkah eksplorasi.

Rata-rata nilai PAM siswa pada kelas yang memperoleh pembelajaran pendekatan eksplorasi berbasis intuisi dan kelas yang memperoleh pembelajaran konvensional yang relatif tidak berbeda. Pengelompokkan siswa berdasarkan PAM dilakukan seperti pada tabel 3.3 
Tabel 3.3 Kriteria Pengelompokkan PAM Siswa

\begin{tabular}{lcccc}
\hline \multirow{2}{*}{ Kelas } & Mean & SD & Mean + 1 SD & Mean - 1 SD \\
\cline { 4 - 5 } & & & Atas & Bawah \\
\hline EBI & 18,00 & 5,94 & Nilai $\geq 23,94$ & Nilai $\leq 12.06$ \\
\hline Konvensional & 17,94 & 5,60 & Nilai $\geq 23,54$ & Nilai $\leq 12.34$ \\
\hline
\end{tabular}

Pengelompokkan berdasarkan PAM secara lengkap dapat dilihat pada tabel 3.4.

Tabel 3.4 Pengelompokkan Berdasarkan Kategori PAM Siswa

\begin{tabular}{c|c|c|c}
\hline \multirow{2}{*}{ Kategori } & \multicolumn{2}{|c|}{ Pendekatan Pembelajaran } & \multirow{2}{*}{ Total } \\
\cline { 2 - 3 } & EBI & Konvensional & 15 \\
\hline Pandai & 8 & 7 & 42 \\
\hline Cukup & 20 & 22 & 17 \\
\hline Lemah & 9 & 8 & 74 \\
\hline Keseluruhan & 37 & 37 & \\
\hline
\end{tabular}

Sebelum melakukan uji ANOVA dua jalur, terlebih dahulu diuji normalitas dan homogenitas varians dari nilai gain ternormalisasi kelas eksplorasi berbasis intuisi dan konvensional secara keseluruhan berdasarkan PAM (pandai, cukup, lemah). Hasil uji normalitas pada KolmogorovSmirnov untuk nilai gain kelas eksplorasi berbasis intuisi dan konvensional secara keseluruhan berdasarkan PAM (pandai, cukup, lemah) diperoleh nilai Sig. > 0,05 maka data berdistribusi normal. Hasil perhitungan uji homogenitas dengan uji Levene Statistic diperoleh nilai Sig. > 0,05 artinya varians data N-Gain secara keseluruhan berdasarkan PAM (pandai, cukup, lemah) adalah homogen. Hasil perhitungan ANOVA dua jalur disajikan pada tabel 3.5.

Tabel 3. 5 Uji ANOVA Dua Jalur Data N-Gain

\begin{tabular}{lcrrrr}
\hline Source & $\begin{array}{c}\text { Type III Sum } \\
\text { of Squares }\end{array}$ & Df & Mean Square & \multicolumn{1}{c}{ F } & \multicolumn{1}{c}{ Sig. } \\
\hline Corrected Model & $1.193^{\mathrm{a}}$ & 5 & .239 & 49.378 & .000 \\
\hline Intercept & 5.286 & 1 & 5.286 & $1.094 \mathrm{E} 3$ & .000 \\
\hline Model & .451 & 1 & .451 & 93.269 & .000 \\
\hline PAM & .645 & 2 & .322 & 66.751 & .000 \\
\hline Model * PAM & .008 & 2 & .004 & .799 & .454 \\
\hline Error & .329 & 68 & .005 & & \\
\hline Total & 7.106 & 74 & & & \\
\hline Corrected Total & 1.521 & 73 & & & \\
\hline
\end{tabular}

Hasil uji ANOVA dua jalur berdasarkan tabel 3.5, yaitu terdapat perbedaan peningkatan kemampuan pemecahan masalah matematis yang signifikan antara siswa yang memperoleh pembelajaran dengan pendekatan eksplorasi berbasis intuisi dengan siswa yang memperoleh pembelajaran matematika menggunakan 
pembelajaran konvensional ditinjau secara keseluruhan berdasarkan PAM (pandai, cukup, lemah), namun tidak terdapat interaksi antara tingkat PAM dengan pembelajaran yang digunakan. Kemudian untuk mengetahui perbedaan peningkatan kemampuan pemecahan masalah matematis siswa antara yang pandai, cukup, dan lemah maka dilakukan uji lanjut Post Hoc Tukey. Hasil perhitungan disajikan pada tabel 3.6.

Tabel 3.6 Uji Post Hoc Tukey Data N-Gain Berdasarkan PAM

\begin{tabular}{lllrrrrr}
\hline & & \multicolumn{2}{c}{ Mean } & & \multicolumn{3}{r}{$95 \%$ Confidence Interval } \\
\cline { 3 - 7 } (I) PAM & (J) PAM & Difference (I-J) & Std. Error & Sig. & Lower Bound & Upper \\
Bound \\
\hline Pandai & Cukup & $.2225^{*}$ & .02091 & .000 & .1724 & .2726 \\
\cline { 2 - 7 } & Lemah & $.2655^{*}$ & .02462 & .000 & .2065 & .3245 \\
\hline Cukup & Pandai & $-.2225^{*}$ & .02091 & .000 & -.2726 & -.1724 \\
\cline { 2 - 7 } & Lemah & .0431 & .01998 & .087 & -.0048 & .0909 \\
\hline Lemah & Pandai & $-.2655^{*}$ & .02462 & .000 & -.3245 & -.2065 \\
\cline { 2 - 7 } & Cukup & -.0431 & .01998 & .087 & -.0909 & .0048 \\
\hline
\end{tabular}

Berdasarkan tabel 3.6, dilihat dari nilai Sig., dapat disimpulkan bahwa terdapat perbedaan peningkatan kemampuan pemecahan masalah matematis antara siswa dengan kategori PAM pandai dan cukup (Sig. $0,000<0,005$ ), terdapat perbedaan peningkatan kemampuan pemecahan masalah matematis antara siswa dengan kategori PAM pandai dan lemah (Sig. 0,087 $>0,05)$, kemudian tidak terdapat perbedaan peningkatan kemampuan pemecahan masalah matematis antara siswa dengan kategori PAM cukup dan lemah (Sig. 0,004 $<0,05)$.

Dari hasil rata-rata $\mathrm{N}$-gain dapat diketahui bahwa peningkatan kemampuan pemecahan masalah matematis siswa yang memperoleh pembelajaran pendekatan eksplorasi berbasis intuisi lebih baik daripada peningkatan kemampuan pemecahan masalah matematis siswa yang memperoleh pembelajaran konvensional berdasarkan tingkat Pengetahuan Awal Matematika (PAM) dengan kategori pandai, cukup, dan lemah. Hal tersebut dikarenakan siswa yang memperoleh pembelajaran pendekatan eksplorasi berbasis intuisi melakukan berbagai aktivitas seperti siswa menjadi penjelajah aktif (active eksplorer), melakukan penyelidikan untuk menemukan konsep, mengkontruksi pengetahuannya sendiri, serta mengemukakkan ide-ide, argumenargumen, dan cara-cara yang berbeda dalam menemukan konsep atau memecahkan masalah. Dengan demikian siswa lebih memahami suatu konsep serta mampu menyelesaikan masalah-masalah. 
Hal ini sejalan dengan yang diungkapkan oleh Sari (2015) bahwa siswa pada tingkat kemampuan yang sama yang memperoleh pembelajaran dengan metode eksplorasi lebih baik daripada siswa yang memperoleh pembelajaran ekspositori dengan skor ratarata 25,73. Mengenai keterlibatan intuisi dalam pembelajaran matematika, Fisthi (2013) menyatakan model pembelajaran

\section{Simpulan dan Saran}

Berdasarkan hasil penelitian dan pembahasan secara garis besar dapat disimpulkan bahwa peningkatan kemampuan pemecahan masalah matematis siswa yang memperoleh pembelajaran pendekatan eksplorasi berbasis intuisi mengalami peningkatan dengan kategori sedang. Peningkatam kemampuan pemecahan masalah matematis siswa yang memperoleh pembelajaran konvensional

\section{Ucapan Terima Kasih}

Penulis mengucapkan terima kasih kepada: Drs. Agus Hikmat Syaf, M.Si. selaku pembimbing I, Dr. Hj. Wati Susilawati, M.Pd., selaku pembimbing II, Drs. H. Idad Suhada, M.Pd. selaku Ketua Jurusan Pendidikan MIPA, Dra. Juariah, M.Pd.,

\section{Daftar Pustaka}

Azmi, M. P. (2015). Penerapan Pendekatan Concrete-Representational-Bbstrac berbasis pada pengembangan intuisi memberikan pengaruh terhadap kemampuan pemecahan masalah matematika. Lebih lanjut, Hasanah (2011) dari hasil penelitiannya memberikan kesimpulan bahwa terdapat peningkatan kemampuan berpikir kritis dan kreatif matematika melalui pendekatan kontekstual berbasis intuisi.

mengalami peningkatan dengan kategori rendah. Pendekatan eskplorasi berbasis intuisi dapat diaplikasikan pada sub pokok bahasan lain, sebagai salah satu alternatif pendekatan pembelajaran dengan aransemen agar siswa mampu beradaptasi dengan konsep yang merupakan kunci awal keberlangsungan proses pembelajaran efektif dan efisien.

selaku Ketua Jurusan Pendidikan Matematika, seluruh staf yang berada di lingkungan Fakultas Tarbiyah dan Keguruan dan kepada pihak sekolah yang telah membantu penulis dalam menyelesaikan penelitian $\mathrm{i}$ 
dan Komunikasi Matematik Siswa SMP. Tesis UPI Bandung: Tidak diterbitkan

Fauziah, A. (2010). Peningkatan Kemampuan Pemahaman dan Pemecahan Masalah Matematik Siswa SMP melalui Strategi REACT. Forum Kependidikan.

Fischbein, Efraem. 1987. Intuition In Science And Mathematics. Israel: School of Education Tel Aviv University.

Fisthi, N. (2013). Eksperimentasi Model Pembelajaran Berbasis pada Pengembangan Intuisi terhadap Kemampuan Pemecahan Masalah Matematika Siswa Pada Materi Turunan Ditinjau Dari Kreativitas Belajar Siswa Kelas XI SMA Negeri 3 Surakarta. (Skripsi). Universitas Sebelas Maret: Surakarta.

Hasanah, A. (2011). Peningkatan Kemampuan Berpikir Kritis Dan Kreatif Matematis Siswa Sekolah Menengah Atas Melalui Pendekatan Kontekstual Berbasis Intuisi . (Disertasi). Sekolah Pascasarjana, Universitas Pendidikan Indonesia: Bandung.

Kadir. (2010). Penerapan Pembelajaran Kontekstual Berbasis Potensi Pesisir Sebagai Upaya Peningkatan Kemampuan Pemecahan Masalah Matematik, Komunikasi Matematik Dan Keterampilan Sosial Siswa SMP. Disertasi pada SPs UPI Bandung: Tidak Diterbitkan.

Kusumawati, N. (2010). Peningkatan Kemampuan, Pemecahan Masalah dan Disposisi Matematis Siswa SMP melalui Pendekatan Pendidikan Matematika Realistik. Disertasi FPMIPA UPI: Tidak diterbitkan.
Lindawati. (2010). Pembelajaran Matematika dengan Pendekatan Inkuiri Terbimbing untuk Meningkatkan Kemampuan Pemahaman dan Matematis Siswa Sekolah Menengah Pertama. Tesis Sekolah Pascasarjana Universitas Pendidikan Indonesia. Bandung.

Mudrika, \& Budiarto, M. (2013). Profil Intuisi Siswa SMP dalam Memecahkan Masalah Geometri Ditinjau dari Kemampuan Matematika Siswa. Jurnal Pendidikan Matematika, 2.

NCTM 2000. Principles And Standards for School Mathematics. Reston, Virginia

NCTM. (1989). Curricullum And Evaluation Standar for School Mathematics. VA: NCTM Inc.

Novianti, Isrok'atun, \& Kurniadi. (2016). Pendekatan Eksploratif untuk Meningkatkan Kemampuan Pemecahan Masalah Matematis dan Motivasi Belajar Siswa. Jurnal Pena Ilmiah, 403.

Rohaeti, E. E. (2008). Pembelajaran dengan Pendekatan Eksplorasi untuk Mengembangkan Kemampuan Berpikir Kritis dan Kreatif Matematika Siswa SMP. Bandung: Desertasi UPI.

Rohmat, I. (2014). Penerapan Pembelajaran Eksploratif untuk Meningkatkan Kemampuan Pemahaman dan Komunikasi Matematis Siswa SMP. Tesis UPI Bandung: Tidak diterbitlkan.

Rusman. (2013). Model-model Pembelajaran: Mengembangkan Profesionalisme Guru. Jakarta: Rajawali Pers. 
Sari, N. M. (2015). Meningkatkan Kemampuan Pemecahan Masalah Matematis dengan Metode Eksplorasi. Alphamath . (2012). Bahan Belajar Mata Kuliah Proses Berpikir Matematika. STKIP Siliwangi 2012: Bandung Tidak diterbitkan.

Susilawati, W. (2013). Perencanaan Pembelajaran Matematika. Bandung: CV Insan Mandiri.

(2014). Belajar dan Pembelajaran Matematika. Bandung: CV. Insan Mandiri.

\section{(2017). Pengaruh}

Pembelajaran Berbasis Tantangan dengan Strategi Konflik Kognitif terhadap Peningkatan Kemampuan Visualisasi Spasial Berpikir Lateral dan Kegigihan Matematis Mahasiswa. (Disertasi). Sekolah Pascasarjana. Universitas Pendidikan Indonesia. Bandung. Tidak diterbitkan.

Turmudi. (2009). Landasan Filsafat dan Teori Pembelajaran Matematika Berparadigma Eksploratif dan Investigatif. Jakarta: Leuser Cipta Pusaka.

(2010). Penalaran dalam Geometri. Universitas Pendidikan Indonesia. Bandung.

Wahyudin. (2008). Pembelajaran dan Model-Model Pembelajaran (Pelengkap untuk Meningkatkan Kompetensi Pedagogis para Guru dan Calon-Guru Propesional). Ipa.Abong: Jakarta. 